UDC 17.023.1 + 374 + 316.7

DOI: 10.15587/2519-4984.2020.199287

\title{
CONTINUOUS EDUCATION AS THE BASIS OF SOCIOCULTURAL ADAPTATION
}

\author{
Ye. Borinshtein, I. Orlenko
}

\begin{abstract}
Актуальність дослідження обумовлена затребуваністю універсальних, евристичних над професійних умінь, щзо дозволяють людині бути успішною та конкурентоспроможною на сучасному ринку праці. Сьогодні важливим фактором успіху трансформацій є здатність до постійної адаптації., щзо ице може бути можливим за умови якісного функиіонування системи безперервної освіти. Тому ми розглядаємо зміст освіти, маючи на увазі комплекс спеціальним чином відібраних, соиіально значущих та необхідних знань, умінь і навичок, засвоєння яких необхідне для формування особистості й активного включення ї̈ в життя суспільства. Метою нашого дослідження є визначення ролі соціокультурної адаптації в безперервній освіті людини з високою конкурентною спроможністю в умовах сучасного суспільства. Саме в ичьому, в периу чергу, полягає иінність професійної мобільної людини.

У дослідженні представлені основні функиії безперервної освіти та виокремлені три головних надпрофесійних вміння, щзо дозволяють людині бути успішною та конкурентоспроможною на сучасному ринку праці. Авторами описаний досвід ефективної співпраці з представниками різних соиіономічних професій, потенційними роботодавцями, фахівцями, батьками, студентами, який дозволяє отримати не тільки практичні навички в обраній професії студентам, а й освоїти нові технології, знання професійних інструментів і методів, необхідних для інноваційної діяльності фахівців. Результатом успішного взаємозв'язку соціокультурної адаптації та соиіалізаџії сучасної людини є готовність до постійного підвищення освітнього рівня, потреба в реалізації свого особистісного потенціалу, здатність самостійно здобувати нові знання та вміння. Найбільш значуще завдання безперервної освіти полягає в створенні умов для особистісного та професійного зростання людини, розвитку ії креативних, творчих здібностей, професійної компетениії в умовах сучасного суспільства.

Запропоноване дослідження сприяє формуванню формуванню системи безперервної освіти, шзо орієнтується на безперервне відновлення $і$ збереження вже наявних трудових ресурсів иляхом створення системи соціальних ліфтів, створення системи якісної безперервної освіти, щзо відповідає компетениіям сучасного розвиненого суспільства, розширення системи безкоштовної безперервної освіти, створення системи дистанційної безперервної освіти при обов'язковій стовідсотковій інтернетизації Украӥни на рівні $4 G$ і вище, підвищення престижу вищої освіти та створення значно більшої кількості безкоштовних місиь у УВО у кожному з регіонів України
\end{abstract}

Ключові слова: неперервна освіта, професійна мобільність, сочіокультурна адаптація, самореалізація, соиіалізація, людина, Ното Неuristicus

Copyright (C) 2020, Ye. Borinshtein, I. Orlenko. This is an open access article under the CC BY license (http://creativecommons.org/licenses/by/4.0).

\section{Introduction}

The greatest value of the modern society is the heuristic person (Homo Heuristicus), who is able to find effective forms of learning new knowledge, to make non-standard decisions. The complexity of social change requires the future specialist of a high level of professional and personal experience, professional and general culture, value self-determination, the ability to carry out their activities in the spirit of tolerance and recognition of the self-worth of each person. This is impossible without understanding the sociocultural bases of human life. Such knowledge will not be complete without taking into account the philosophical principle of additionality, which shows the need to study simultaneously the rational and irrational sides of reality, the essence of simultaneity of the irrational and rational sides of Homo Heuristicus life.
On the basis of which, there is an understanding of the emergence of new sociocultural forms and meanings that complement each other and are directly dependent on the assimilation, acceptance and reevaluation of the past sociocultural heritage. But this would not be possible without the participation of education as a unique sociocultural mechanism for the development of human and society, which makes it possible for a person to form his or her individual lifestyle in society and culture.

In modern scientific knowledge it is possible to distinguish a number of directions of understanding of the category "education" (the original meaning begins to

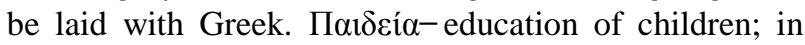
modern scientific knowledge the English term is "education"): 
1) personified system of transfer of the accumulated knowledge, skills and competences in all areas of life from generation to generation;

2) the system of life of the society, related to purposeful training, upbringing, transfer of acquired knowledge, abilities, skills and value orientations;

3) social institute, responsible for transferring knowledge, abilities, skills and social experience from one person (group) to another;

4) "the process and result of the enhancement of the faculties and behaviors of an individual, in which they reach maturity and individual growth" (definition, adopted by the XX UNESCO General Conference in 1978);

5) set of systematic knowledge, abilities and skills, acquired by an individual both independently and in the course of training in special educational institutions.

Based on the focus of the article, we are not only interested in education as a process, but also in the content of education, its essence, semantic and strategic components. Therefore, we consider the content of education, implying under it a complex of specially selected, socially significant and necessary knowledge, abilities and skills, the assimilation of which is necessary for the formation of personality and incorporation of it into society.

It should be noted, that the dynamic transformations of the 21 st century, which affected virtually all aspects of society and radically changed it (society EB, IO), are characterized by global sociocultural changes and cardinal transformations of the education system. Today, the ability to constantly adapt is an important factor in the success of transformations. This is only possible with the help of quality functioning of the system of continuous education.

\section{Literary review}

The specificity of the influence of globalization processes on the development of continuing education is highlighted in the works of modern Ukrainian scientists [1-3].

Modern science [2] considers continuous education through the prism of certain functions, such as: sociocultural, developmental, general education, compensatory, adaptive (flexible vocational training, retraining and advanced training for the purpose of updating professional experience, obtaining another profession in the conditions of constant changes) (meeting the needs of the state in competitive specialists). Highlighting the main features and functions of continuing education, the scientist does not address the issues of labor migration in the context of modern occupational mobility of human [2].

There is an opinion that pedagogical technologies of creative development of pupils and teachers are an actual solution to the problem of holistic preparation and retraining of pedagogical staff. In the process of pedagogical creativity, the development of students serves as the goal of the teacher's activity, as well as a means of creative development of the teacher's personality, enhancing his/her professional competence and level of pedagogical skill. However, the author does not consider the impact of continuing education on the professional competencies of a teacher, which would allow him/her to be competitive in the modern Ukrainian society [3].
More systematically, from our point of view, the essence of continuous education is revealed through the prism of the philosophy of education [4]. According to the researchers of this area, continuous education is an education that allows a person to be constantly in the common line of development of civilization, to maintain their competitiveness during life, provides an opportunity in the process of learning to quickly, systematically and consistently acquire new knowledge, information as it is permanently accumulation and development, that isto navigate in a complex and powerful flow of information, updated at lightning speed, confidently exist and develop in society is information throughout life [4]. However, his research does not address the current globalization issues of continuing education from the point of view of sociocultural adaptation, affecting the quality of life of labor migrants and the economic status of the country as a whole.

Foreign scientists view continuous education through the sociocultural lens. Thus, studying the process of sociocultural adaptation of ImS employees by means of inductive qualitative research, the author believes that migrations of the working population imply further training of ImS employees, who have previously had problems with employment and the consequent various life problems, to improve their quality of life. Intensification of the process of sociocultural adaptation can lead to the development of the most important individual and collective abilities. In conclusion, the author describes a model for developing the capabilities of ImS employees and discusses the implications for ImS companies [5].

The modern research in the field of global mobility of successful multispecialists demonstrates how individual choice is made through framework positions. According to this study, companies operating in emerging markets invariably require their employees to be geographically mobile, but organizational and individual needs do not always match. Based on the theory of frames, scientists demonstrate how successful specialists of a company participate within framing, when represented the requirements of organizational mobility. Based on this study, the authors have outlined a typology of four positions of staff mobility: acceptance, adaptation, avoidance and renunciation. Is has a profound effect on the issues of sociocultural mobility and continuous training of employees [6].

Education plays a significant role in the process of modernization of society, promoting mutual understanding and intercultural dialogue, being the center of preparation of a new generation of specialists and leaders, being a specific form of dialogue, in which the systems of subject-object and subject-subject relations are creatively constructive [7].

The analysis of the literature makes it possible to conclude that the attention of the world scientific community is paid to the issues of continuous education in various aspects of personnel policy, but the question of sociocultural adaptation of labor resources remains poorly understood. This has determined our interest in studying the role of sociocultural adaptation of a professional mobile person, the formation of his/her functional capa- 
bilities with the help of a system of continuous education in the conditions of modern society with the high competitive ability. The guiding principle of lifelong learning is the fact that its entire system is oriented towards the formation of adaptation to the rapidly changing conditions of the sociocultural and professional space and the desire to acquire new knowledge. "Learning to learn" is the main purpose of learning in its institutional forms, which enables a person to increase the personal and professional level of education and culture throughout his/her life [8].

\section{The purpose and objectives of the study:}

The purpose of the study is to study the functioning of the system of continuous education as a basis for sociocultural adaptation.

To achieve the goal, the following tasks were set:

1. To determine the role and importance of continuing education in the modern society;

2. To substantiate the value of a professional mobile person for a society with high competitiveness;

3 . To study the influence of sociocultural adaptation in continuing education on self-realization and functioning of a competitive society;

4. To distinguish between successful socialization and sociocultural adaptation of a person.

\section{The value of continuing education as the ba- sis of sociocultural adaptation for modern society and human.}

The formation of a system of continuous education, we think, is directly dependent on the sociocultural problems facing a particular society. At the same time, the role of sociocultural adaptation cannot be underestimated as an aggregate of processes and skills for adapting people. It allows us to consider education as a factor and as the basis of sociocultural adaptation. One of the prerequisites for the creation of continuity of education is the design of the entire education system, taking into account the conditions for the conscious learning of the values of culture as an integral need of an individual.

This idea was expressed by Plato and Aristotle; it was also reflected in the humanistic views of Ya. A. Komensky, J.-J. Rousseau. This idea did not also leave indifferent such progressive educators of the XIX century as N. I. Pirogov and K. D. Ushinsky.

According to the researcher, we agree with, continuous education is a multilevel concept that covers different directions of the human educational activity depending on social, economic and individual needs [9]. The quality of continuing education depends on the future of the country. It is continuous education that forms the richest resource of the state-human potential.

But the human potential and the consequence of its disclosure - accumulated human capital - do not arise of nowhere, they are created. This requires a system of continuous education, a system of higher education as a means of accumulating professional knowledge and the formation of the middle class. It is the system of lifelong education, which influences the professional mobility of a person, provides additional career opportunities.

In the context of the above, the researchers analyzed the impact of HR management practices at the country level on the professional and career growth of its specialists. Using qualitative methods, this study shows us new dimensions of career evaluation for successful people with an international education: the use of knowledge, gained abroad, and the international dimension of work. Based on this data, the authors developed a model of career types. Career types predict different degrees of success in the career of professionals and their participation in the exchange of knowledge, ideas of their international experience, which can have an impact on society. The results of this study can make a significant contribution to the field of global management of professional success and career growth, based on the impact of continuing education on these processes [10].

By continuous education we mean the systematic, state-organized acquisition, assimilation and refinement of knowledge, abilities and skills, which gives a person maximum opportunities for self-realization and adaptation.

Processes of self-realization and adaptation in general are extremely important for a person, being as though barometers of his/her success. In this case, selfrealization is important for a person, in our opinion, as a process of awareness of one's own talent, abilities and inclinations, followed by their embodiment in any form. Aristotle expressed himself well, stating that "happiness is attainable through the realization of our potential" [11]. And here I would like to emphasize the importance of social self-realization, by what we mean the achievement of success in interpersonal relationships, in society, in such quantity and quality, which bring satisfaction and a sense of happiness to a person, and are not limited to established patterns and stereotypes.

When developing strategies for self-realization, the state needs to be aware that its success-failure is directly dependent on social adaptation as a process of active adaptation to certain material conditions, norms and values of the social environment and sociocultural adaptation, by which we denote the process of active adaptation of individuals, human communities, social and cultural groups to transforming social, cultural, historical and natural conditions of their lives through changing Nia stereotypes of consciousness and behavior, forms of social organization and regulation, norms and values, lifestyles and patterns of elements of the world, ways of subsistence, trends and technology activities, communication of mechanisms, broadcasting and retransmission of a social experience.

Considering sociocultural adaptation through the prism of axiology, we will certainly pay attention to the social factors of cultural values and norms, their impact on society and social human behavior. Therefore, speaking of sociocultural adaptation in the context of social cognition, we see a number of features of social cognition, which are expressed in the fact that the object of cognition is society, the human world, its conscious activity, its creation of values [12]. Therefore, sociocultural adaptation affects the targeted assimilation of a sociocultural experience using the achievements of all the components of the continuing education system.

One of the most significant properties of lifelong education is that it becomes a vital tool to help a person productively overcome situations of sociocultural and professional maladaptation. 
To prevent this from happening, a project of continuing education among students was developed and successfully implemented, which consists in creating conditions for continuing education within the university, so that the university, the graduating department and employers with whom the department works closely, have an idea of the professional characteristics of students.

At the Department of Philosophy, Sociology and Management of Sociocultural Activities of Ushinsky University (Odessa), the School of Logistics and the School of Guides have been created and are successfully functioning. The department works closely with the city hall (students practice in various departments), organizations "Solar children", "School of the First", "Eco Planet Foundation", "Creative Marathon". Regular meetings are held with representatives of socionomy professions, seminars, trainings, participation in social projects-all this allows students to gain practical skills in their chosen profession.

Today, when in Ukraine, continuing education courses, as one of the types of lifelong education, are conducted not only by institutes of postgraduate education, but also by SVE (higher education institutions), public organizations, and educational centers, there are additional opportunities for developing a lifelong education system in Ukraine. According to the Cabinet of Ministers resolution, from January 1, 2020, teachers can use the funds, allocated by the state for advanced training and study at their chosen organizations. This allows specialists to obtain the knowledge and skills that they currently need, which are relevant in this situation in each profession. What the department of philosophy, sociology and management of sociocultural activity uses. So, agreements were concluded with the Public Association "Healthy Society" in Odessa and the Center for Early Intervention, offering training courses and seminars not only for specialists, but also for parents and students. Involved in the work are specialists, who are continuously improving their skills at international seminars and trainings, held in Kharkov, Lviv, Uzhgorod, St. Petersburg, Amsterdam, which gives them the opportunity to share their professional experience in corporate courses and at the annual summer school.

Changes, taking place in the modern global world, are making increased demands on specialists in all areas of activity. When the Heuristic person understands that for the successful implementation of the assigned professional tasks, his/her knowledge is not enough-he/she is included in the system of continuing education.

We completely agree with the well-known UNESCO functionary G. Dave, who believed that “... lifelong education is a process of personal, social and professional development of an individual throughout his/her life, carried out with the aim of improving the quality of life of both an individual and society. This is a comprehensive and unifying idea that encompasses formal and non-formal education, which is carried out with the aim of achieving the most complete development of various aspects of life at its various stages. It is associated both with the development of personality and with social progress [13].
It seems to us that the impact of lifelong education on the modern Homo Heuristicus is the most important, appreciating knowledge above all, the possibility of creative activity, longing for maximum selfrealization and focusing on the constant growth of one's potential, including potential, throughout life.

\section{Research results and discussion}

The study of sociocultural adaptation from the perspective of lifelong education leads to the idea that it is necessary to consider its significance not only at the personal level, but also its role in the development of a multicultural society. The concept of "education" contains the trinity of a holistic process that conveys the sociocultural experience of previous generations, cultivates the typological qualities of an individual and develops cognitive abilities of a person.

Based on data from international studies, scientists made a comparative analysis of continuing education of adults. Data from the International Adult Literacy Survey (IALS) were analyzed to compare the frequency and volume of continuing education (CE) among adults in the following countries: Australia, Belgium, Canada, Ireland, the Netherlands, New Zealand, Poland, Switzerland, the United Kingdom and the United States. The results of the comparative analysis can serve as a confirmation of the importance of lifelong education throughout the world, namely: in all 10 countries, employed adults more often than unemployed participate in continuing education programs; participation in professional retraining programs is much more frequent than training for personal reasons; more often people with a higher level of education continue to study; young people are more mobile and more often senior colleagues participate in training programs; employees of large companies are more likely to participate in CE programs; in all countries studied, employers were the most common financial sponsors of all training. Based on the data, obtained during the comparative analysis, we see that large companies are interested in continuing education of their employees, which increases both the level of employment and the standard of living in these countries [14].

Based on sociocultural anthropology, one of the foreign scientists [15] considered the consequences of the resumption of anthropological interest in materiality and cultures arising from the interaction between people, nonhuman agents, and the material environment. The work illustrates the power of anthropology in identifying contradictions, compromises and unlikely relationships of life experience in the material world. The author focuses on the sociocultural processes, taking place in the continuous training of people, that become real thanks to the actions of people and interaction with others, touching on the themes of the emergence of sociocultural changes; bureaucracy in modern life; the relationship of research and public policy; adaptation and emotions in everyday life and the importance of interdisciplinary research on lifelong learning of adults [15].

According to the National Institute for Strategic Studies, the functions of continuing education are: developing (satisfying the spiritual needs of an individual, the needs of creative growth), compensating (filling in the gaps in basic education), adaptive (operational train- 
ing and retraining in a changing industrial and social situation); integrating into an unfamiliar sociocultural context; the function of resocialization [16-18].

The analysis of the results of the study allowed us to highlight the role of the influence of society on the success of sociocultural adaptation, with the inclusion of a personality in the process of lifelong education.

Visiting the School of Guides at Ushinsky University, students master the knowledge of how to make an excursion program, an excursion interesting, fascinating and informative. The program includes historical and cultural information, acquaintance with the history and culture of Odessa, its traditions. During the classes of the school of guides, master mentors reveal tricks with which you can interestingly reveal excursion topics, to answer the most unexpected questions correctly and with humor.

Studying at the "School of Logistics" (founded by one of the authors of the article, E. R. Borinstein), students gain knowledge, skills and abilities about the possibilities of integrating various fields of knowledge into a single system, aimed at the ability to systematically assess the situation; at the same time, the creative abilities of a creative person develop, which is the basis of Homo Heuristicus.

According to the results of our study, I would like to mention not only the "School of Guides", "School of Logistics", the work of the NGO "Healthy Society", the Center for Early Intervention and ORCPIO, as well as the employment project "Be Successful" with the support of the WJR England charity foundation. The aim of the project is to help you realize yourself, the opportunity to become in demand on the modern labor market, competitive. In the project, you can master the skills of self-presentation, identify personal qualities to determine a successful career, and certainly work with goal-setting - setting new goals for motivating life. And having passed such a course of career-oriented diagnostics and selfpresentation, project participants are given the opportunity to master new, relevant professions in the modern labor market.

The above-described forms and directions of lifelong education create, on the basis of newly obtained data and information, a person's ability to develop new approaches and make innovative decisions. Consequently, a creative approach to solving professional problems allows a specialist to be more effective in his professional activity.

In the modern world, professional knowledge is rapidly becoming obsolete; new knowledge is replacing it. The demand for creative thinking today is associated primarily with a high level of competition, characteristic of almost any industry. And highly qualified communicative specialists, quickly mastering new rules and technologies, adaptive to changes, are a valuable resource of any company, any country.

A heuristic person (Homo Heuristicus) is the owner of super-professional skills. And on the basis of our research, we identified three main supra-professional skills that allow a person to be successful and competitive in the modern labor market: creative thinking, motivated self-education and leadership qualities.
It is difficult to overestimate the role of lifelong education for the implementation of a socially integrated system of educational complexes of the country. Its uniqueness lies in the fact that continuing education is ahead of the planned nature and applies to all levels of education. For a concrete person, it acts throughout life, for the state it is continuous.

It seems to us significant the role of lifelong education in the reproduction of labor resources, since migration in the globalized society is a constant and natural process. And it is lifelong education as the basis of sociocultural adaptation that can form the process of continuous renewal of the quantitative and qualitative characteristics of the economically active population. Continuing education as the basis of sociocultural adaptation opens up additional opportunities for preserving existing labor resources. To preserve labor resources, in our opinion, it is necessary:

$\infty$ creation of a system of social elevators, when a fast-adapting person is able to quickly make a social career;

$\infty$ creation of a system of quality continuing education, corresponding to the competencies of a modern developed society, in which a person realizes that continuing education in Ukraine, meets European and international standards;

$\infty$ expansion of the system of free continuing education, since only the free option will allow you to compete with developed countries in the context of labor retention, because the quality of all services, provided in developed countries is incomparably higher;

$\infty$ creation of a system of distance learning with the mandatory $100 \%$ internetization of Ukraine at the level of $4 \mathrm{G}$ and higher, which will provide additional opportunities, without moving, to simultaneously work and receive a quality education, adapting to a constantly transforming market;

$\infty$ enhancing the prestige of higher education and creating a significantly larger number of free places in UVO in each of the regions of Ukraine, since it is people with higher education, who seek continuous education and continuous improvement of their professional mobility, including the need to simplify the possibility of entering universities in Ukraine by allowing admission to contractual places to applicants, who have not passed ZNO. Thus, the whole country will be in the system of accumulation of the human capital and the constant replenishment of qualified labor resources.

\section{Conclusions}

1. The formation of new qualities of public consciousness and scientific thinking occurs at the time of the global sociocultural transformation of society, which determines the paradigm shift in the new methodology of continuing education. According to which, the role and importance of lifelong education is to create the conditions for personal and professional growth (Homo Heuristicus) of a heuristic person, the development of his/her creative, creative abilities, professional competence in the modern society.

2 . The presence of a creative employee in any organization is its competitive advantage. A high level of sociocultural adaptation, the desire to develop their crea- 
tive abilities, implement creative ideas, allows Homo Heuristicus to be not only competitive, but also to feel self-realized, successful in the chosen professional path. In this, in the first place, lies the value of a professional mobile person.

3. The influence of sociocultural adaptation in lifelong education on the self-realization of an individual and the functioning of a competitive society is the constant updating of professional skills. The requirements are changing not only to the competencies of a specialist, but also to his/her working tools. And an excellent knowledge of professional tools and methods, necessary for the innovative activity stems from the desire for selfrealization, relaying the specialist's need for continuous learning of something new.
4. The relationship of successful sociocultural adaptation and socialization of modern human forms a willingness to constantly increase the educational level, the need for updating and realizing one's personal potential, the ability to independently acquire new knowledge and skills, developing one's own abilities, and the desire for self-realization in socially useful activities and affects the existence of human in a world of many cultures, filled with many meanings.

5. The labor market in Ukraine needs highly qualified labor resources, which cannot be done without creating a system of lifelong education that focuses on the needs of the modern society and creates the conditions for maximum sociocultural adaptation of a person.

\section{References}

1. Dave R. Lifelong Education and School Curriculum. Hamburg, 1973. P. 14-25.

2. Nychkalo N. H. Neperervna profesiina osvita: problemy, poshuky, perspektyvy: monograph / ed. by Ziaziun I. A. Kyiv: Vipol, 2000. 636 p.

3. Sysoieva S. O. Osnovy pedahohichnoi tvorchosti: textbook. Kyiv: Milenium, 2006. 346 p.

4. Andrushchenko V., Huberskyi L. Filosofiia yak teoriia ta metodolohiia rozvytku osvity. Filosofiia osvity: poshuk priorytetiv. Book 3. Kyiv: «MP Lesia», 2012. 568 p.

5. Sandeep M. S., Ravishankar M. N. Sociocultural transitions and developmental impacts in the digital economy of impact sourcing // Information Systems Journal. 2017. Vol. 28, Issue 3. P. 563-586. doi: http://doi.org/10.1111/isj.12149

6. Tansley C., Kirk S. You were created - talent mobility in emerging markets // Thunderbird International Business Review. 2018. Vol. 60. P. 39-51. doi: http://doi.org/10.1002/tie.21887

7. Borinshtein Ye., Atamaniuk Z., Ortynska N. Education: Dialogical search and socio-cultural adaptation // Science and education. 2017. Issue 12. P. 140-145.

8. Binde J. L'education au XX le siecle: l'education pour tous tout au long de la vie // Futuribles. 2000. Issue 250. P. 5-21

9. Pavlyk N. P. Zmist poniattia neperervna osvita: proceedings // Aktualni problemy v systemi osvity: zahalnoosvitnii navchalnyi zaklad - douniversytetska pidhotovka - vyshchyi navchalnyi zaklad. Kyiv: NAU, 2016. P. 180-182. URL: http://eprints.zu.edu.ua/23616/1/\%D0\%9F\%D0\%B0\%D0\%B2\%D0\%BB\%D0\%B8\%D0\%BA_\%D0\%9A\%D0\%BE\%D0\%BD\% D1\%84\%D0\%B5\%D1\%80\%D0\%B5\%D0\%BD\%D1\%86\%C2\%A6\%D1\%8F \%D0\%9D\%D0\%90\%D0\%A3.PDF

10. Abeuova D., Muratbekova Touron M. Global talent management: Shaping the careers of internationally educated talents in developing markets // Thunderbird International Business Review. 2019. Vol. 61, Issue 6. P. 843-856. doi: http://doi.org/10.1002/tie.22085

11. Samorealizatsiia i smysl zhizni. URL: https://amurmedia.ru/news/12.05.2015/samorealizaciya-i-smysl-zhizni.html (Last accessed: 24.03.2020)

12. Borinshtein Ye. R., Kisse A. I., Orlenko I. M. Sotsyokulturnaia adaptatsyia ynostrannoi molodezhy k ukraynskoi studencheskoi srede: antroposotsyohenetycheskyi kontekst // Hrani. Naukovo-teoretychnyi almanakh. 2018. Vol. 21, Issue 12. P. 42-52.

13. European Commission (EC). A Memorandum on Lifelong Learning. Commission Staff Working Paper. Brussels: European Commission. 2000. URL: https://arhiv.acs.si/dokumenti/Memorandum_on_Lifelong_Learning.pdf (Last accessed: 18.01.2020)

14. O'Connell P. J. Adults in Learning: An International Comparison of Continuing Education and Training. 1999. URL: https://www.semanticscholar.org/paper/Adults-in-Training\%3A-An-International-Comparison-of-

O'connell/b7423ae39f2d1da0aff502db684471694c5f63a2

15. Koenig D. The Year 2015 in Sociocultural Anthropology: Material Life and Emergent Cultures // American Anthropologist. 2016. Vol. 118, Issue 2. P. 346-358. doi: http://doi.org/10.1111/aman.12530

16. "Osvita protiahom zhyttia: svitovyi dosvid i ukrainska praktyka". Analitychna zapyska. Natsionalnyi instytut stratehichnykh doslidzhen. URL: http://old2.niss.gov.ua/articles/252/ (Last accessed: 17.01.2020) 2005. 448 p.

17. Kremen V. H. Osvita i nauka v Ukraini - innovatsiini aspekty. Stratehiia. Realizatsiia. Rezultaty. Kyiv: Hramota,

18. Osvita doroslykh: bibliohrafichnyi pokazhchyk. Kyiv: TOV «DKTs-Tsentr», 2016. $144 \mathrm{p}$

Received date 06.02.2020

Accepted date 18.02.2020

Published date 31.03.2020

Evgenij Borinshteyn, Doctor of Philosophical Sciences, Professor, Department of Philosophy, Sociology and Management of Social and Cultural Activities, State Institution "South Ukrainian National Pedagogical University named after K. D. Ushynsky”, Staroportofrankivska str., 26, Odessa, Ukraine, 65020

Email: eborin197013@gmail.com

Irina Orlenko, Postgraduate Student, Department of Philosophy, Sociology and Management of Social and Cultural Activities, State Institution "South Ukrainian National Pedagogical University named after K. D. Ushynsky”, Staroportofrankivska str., 26, Odessa, Ukraine, 65020

Email: ptichka.net@i.ua 